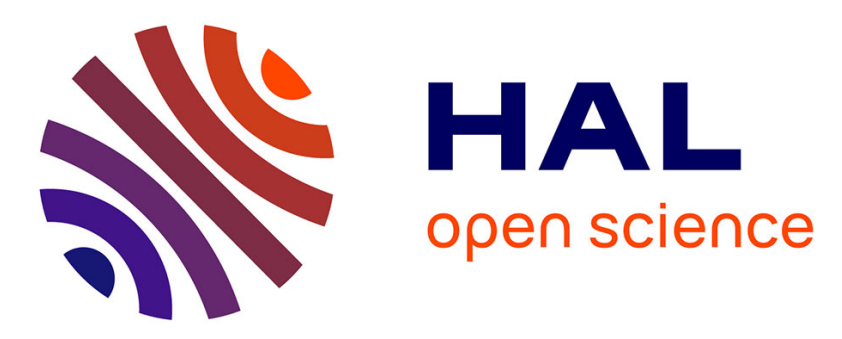

\title{
Inhibition of viral replication in vitro by antiviral-treated amniotic membrane.Possible use of amniotic membrane as drug-delivering tool.
}

Rita Mencucci, Iacopo Paladini, Ugo Menchini, Jean Jacques Gicquel, Rosanna Dei

\section{To cite this version:}

Rita Mencucci, Iacopo Paladini, Ugo Menchini, Jean Jacques Gicquel, Rosanna Dei. Inhibition of viral replication in vitro by antiviral-treated amniotic membrane.Possible use of amniotic membrane as drug-delivering tool.. British Journal of Ophthalmology, 2010, 95 (1), pp.28. 10.1136/bjo.2010.179556 . hal-00576624

\section{HAL Id: hal-00576624 \\ https://hal.science/hal-00576624}

Submitted on 15 Mar 2011

HAL is a multi-disciplinary open access archive for the deposit and dissemination of scientific research documents, whether they are published or not. The documents may come from teaching and research institutions in France or abroad, or from public or private research centers.
L'archive ouverte pluridisciplinaire HAL, est destinée au dépôt et à la diffusion de documents scientifiques de niveau recherche, publiés ou non, émanant des établissements d'enseignement et de recherche français ou étrangers, des laboratoires publics ou privés. 


\section{Inhibition of viral replication in vitro by antiviral-treated amniotic membrane. Possible use of amniotic membrane as drug- delivering tool.}

Rita Mencucci MD,* Iacopo Paladini MD,* Ugo Menchini MD,* Jean Jacques Gicquel $\mathrm{MD},{ }^{* *}$ Rosanna Dei PhD.***

*Department of Oto-Neuro-Ophthalmological Surgical Sciences, Eye Clinic; University of Florence, Italy

** Department of Ophthalmology, Poitiers University Hospital, Poitiers, France

*** Department of Public Health-Microbiology Unit - University of Florence, Florence, Italy

Corresponding author:

Rita Mencucci:

Department of Oto-Neuro-Ophthalmological Surgical Sciences - Eye Clinic, Viale GB

Morgagni 85, 50134 Florence, Italy

Tel.+39-055-411765

FAX.+39-055-4377749

E-mail: rita.mencucci@unifi.it

Requests for reprints should be sent to Rita Mencucci

E-mail: rita.mencucci@unifi.it

Licence for Publication: The Corresponding Author has the right to grant on behalf of all authors and does grant on behalf of all authors an exclusive licence (or not exclusive for government employees) on a worldwide basi sto the BMJ Publishing Group Ltd to permit this artiche (if accepted) to be published in BJO and any other BMJPGL products and sublicences such use and exploit all subsidiary rights as set out in our licence.

Competing Interest: None declared.

Keywords: amniotic membrane transplantation, antiviral-treated amniotic membrane

Word Count (excluding, title page, abstracts and tables): 2298 


\section{Abstract}

Purpose: To investigate if amniotic membrane (AM) incubated with antivirals can inhibit viral growth in vitro.

Methods: AM samples were incubated with a solution of acyclovir (ACV) or trifluridine (TFU). AM treated was placed onto a monolayers of Vero cells, a continuous cell line from monkey kidney, infected with Herpes Simplex Virus (HSV). Viral growth was assessed in comparison to control infected cells by direct examination with an inverted microscope at low magnification for the presence and extension of the typical cytopathic effect, or by estimation of viral genomes.

Results: AM soaked in ACV or TFU inhibited significantly the development of HSV in cell cultures, based on the viral growth compared to controls. Non-treated AM did not significantly affect viral replication.

Conclusions: Our preliminary in vitro data show that antiviral-treated amniotic membrane can inhibit viral replication. Therefore, it could be taken into consideration the possibility to combine the previously published anti-inflammatory properties of AM with the capability to absorb antivirals and sustain drug release.. 
The use of amniotic membrane (AM) in the treatment of epithelial defects dates around the first quarter of $20^{\text {th }}$ century; its use in the treatment of epithelial defect ophthalmology was first reported in 1946.[1] Later only a few reports only were published.[2,3] The breakthrough came with the development of modern preservation technology.[4,5] The use of fresh AM is hindered by the risk of transmission of blood-borne infections; this made necessary to improve cryopreservation, although differences between fresh and cryopreserved AM have been reported.[6]

AM, consisting of thick basement membrane and an avascular stromal matrix, is able to express multiple anti-angiogenic factors, anti-inflammatory proteins, growth factors, and protease inhibitors. The recent surge of interest in the ophthalmic uses of AM has led to its application in a large number of conditions for a variety of indications like, among others, conjunctival and corneal reconstruction, inflammatory disorders, and ocular infections.[4,5,7] Many mechanisms have been invoked in relation to its clinical application, such as reduction of inflammation, inhibition of vascularization, anti-infective properties, promotion of epithelialization, and limitation or prevention of scarring.[8-10]

Amniotic membrane transplantation (AMT) has become somehow a routine intervention in a variety of ocular pathologic conditions, infective or not.[11] When used as a graft (epithelial side up), AM is expected to become incorporated in the recipient tissue. If it is used as a patch (epithelial side down), it works as a biological bandage affording cover for a limited duration or a combination of these. The use of AM has been also suggested in the treatment of infectious keratitis, because of its intrinsic anti-infective properties probably mediated by its anti-inflammatory effects, and because AM may act as a long term drug delivery system.[1214] In this respect, the utilization of AM also in wound healing, skin lesions, and burns has to be mentioned.[15-18] 
Addressing the use of AM to deliver drugs, we had previously reported the antibacterial activity of antibiotic (Netilmicin)-treated AM in an in vitro model. Antibiotic uptake was dose-dependent, and occurred rapidly; our observations seemed promising in view of the possible clinical applications.[19]

AMT has been recently proposed for the management of ulcerative and necrotizing herpetic stromal keratitis in conjunction with antivirals and corticosteroids.[20] In Europe, nucleotide analogues such as Acyclovir ${ }^{\circledR}$ and Trifluridine ${ }^{\circledR}$ are often used topically for the treatment of stromal herpes keratitis. Acyclovir ${ }^{\circledR}$ is a synthetic purine nucleoside analogue with in vitro and in vivo inhibitory activity against herpes simplex virus types 1 (HSV-1), 2 (HSV-2), and varicella-zoster virus (VZV). The inhibitory activity of Acyclovir is highly selective due to its affinity for the enzyme thymidine kinase (TK) encoded by HSV and VZV. This viral enzyme converts Acyclovir ${ }^{\circledR}$ into Acyclovir ${ }^{\circledR}$ monophosphate, a nucleotide analogue. The monophosphate is further converted into diphosphate by cellular guanylate kinase and into triphosphate by a number of cellular enzymes. The block of viral DNA is accomplished in three ways: 1) competitive inhibition of viral DNA polymerase, 2) incorporation into and termination of the growing viral DNA chain, and 3) inactivation of the viral DNA polymerase. Trifluridine is a synthetic pyrimidine nucleoside analogue which inhibits enzymes of the DNA pathway and is incorporated into progeny viral DNA (but also cellular) causing imperfect transcription of late mRNA, hence the production of useless viral proteins. Its range of activity includes HSV1, HSV2, CMV, vaccinia virus, and possibly adenovirus. Because of its toxicity, topical preparations only are available.[21] The aim of our study was therefore to evaluate $\mathrm{AM}$ as a delivering system for antiviral drugs. We report an in vitro study assessing the inhibition of viral replication by AM treated with ACV and TFU. 


\section{Materials and Methods}

AM: The Tuscan regional cornea bank, Lucca, Italy kindly donated the human material. One preserved AM was threphined into $10 \mathrm{AM}$ samples, diameter 2,5 $\mathrm{cm}$. Each sample was weighted.

Virus: A clinical isolate of HSV 1 from an oro-facial lesion was used throughout the study. A stock suspension of the virus grown in cell cultures was aliquoted and stored frozen.

Antivirals: Acyclovir ${ }^{\circledR}(\mathrm{ACV})$, for IV use, $250 \mathrm{mg}$, and Trifluridine ${ }^{\circledR}$ (TFU) 1\%, eyedrops were used in the study. ACV was dissolved in Balanced Salt Solution (BSS, ICN Biomedicals Inc. Aurora, OH, USA) to $50 \mathrm{mg} / \mathrm{ml}$; ACV solution and TFU eyedrops were further diluted in BSS, down to $10 \mathrm{mg} / \mathrm{ml}$ the first and $0.08 \mathrm{mg} / \mathrm{ml}$ the latter.

AM preparation: The AMs were trephined into $7 \mathrm{~mm}$ diameter samples, with a corneal trephine (Operaid, OPHTEC Groningen, The Nederlands). The samples were washed 5 min in BSS, laid onto a sterile gauze to remove the excess of liquid, and then placed in individual wells of 24-well microplates containing $0.5 \mathrm{ml}$ of the antiviral solution or BSS (control). After 60 minutes incubation at $37^{\circ} \mathrm{C}$ on a benchtop shaker, the fluid was aspirated. The AM samples were washed 3 times $\times 5$ min in BSS to remove the non adsorbed drug, and the excess of liquid removed by draining.

Cell cultures: Vero cells, a continuous cell line from monkey kidney were purchased from Istituto Zooprofilattico Sperimentale della Lombardia e dell'Emilia-Romagna, Brescia, Italy. Vero cells monolayers appear by direct inspection of the culture plates through an inverted tissue culture microscope (LEICA DMIL, LEICA Wetzlar, Germany) as polygonal-shaped cells firmly attached to the bottom of the culture vessel. Cells were grown in Minimal Essential Medium (MEM)-10\% Fetal Calf Serum (FCS) (ICN Biomedicals Inc. Aurora, OH, USA). 
Cell cultures infection and assessment of viral replication: Vero cells were used $24 \mathrm{hr}$ after seeding in 24-well plates, when they reached semi-confluence as assessed by inverted microscope examination. The growth medium was removed, and the cell monolayers washed. Cells were inoculated with $200 \mu \mathrm{l}$ viral suspension. After a 90 minutes incubation at $37^{\circ} \mathrm{C}$ in $5 \% \mathrm{CO}_{2}$, the inoculum was removed, and $1 \mathrm{ml}$ of the maintenance medium (MEM-2\% FCS) was added. One AM sample (either antiviral-treated or BSS-treated) was placed, epithelial side up, over the cell culture in each well. Plates were incubated at $37^{\circ} \mathrm{C}$ in $5 \% \mathrm{CO}_{2}$ up to 5 days. Cell monolayers were inspected daily to evaluate, in comparison to monolayers of noninfected cells and infected cells without addition of AM, the development of the typical cytopathic effect (CPE): rounding up (large round cells starting in cluster or small foci, which then extend to the entire monolayer) and detachment of cultured cells.

Antiviral activity CPE extent: Each monolayer was observed at low magnification, 40X, with the inverted microscope; 10 diameters per well, that is experimental point, were considered for the presence of clusters of enlarged round refractile cells in individual wells. The presence and extension of CPE was recorded as percentage of each monolayer showing the morphologic changes. Viral DNA assessment. It was carried out by Quantitative-PCR by means of HSV2 Q-PCR Alert (Nanogen Advanced Diagnostics, Buttigliera Alta (TO), Italy) following the manufacturer's instructions. Briefly, at the end of the incubation period, the cultures were harvested, pooled according to treatment, washed and resuspended in equal volumes of lysing solution. The oligonucleotide mixture was added to the reaction mixture, together with the specific fluorescent probe; and $20 \mu \mathrm{l} /$ well were transferred to the amplification microplate. Five $\mu \mathrm{l}$ of lysed samples were added, the plate sealed and transferred to the real time thermal cycler. Positive $\left(10^{5}\right.$ to $10^{2}$ HSV DNA copies $)$ and negative (sterile distilled water) controls were carried out in parallel. Viral DNA copies were evaluated in comparison to the positive controls. 
Results were expressed as means $\pm \mathrm{SD}$, and evaluated by one-way ANOVA and the Bonferroni multiple comparison test. 


\section{Results}

The weight of the ten AM samples averaged $0.23 \mathrm{~g} \pm 0,06$, range: $0.16-0.30 \mathrm{~g}$, indicating a certain variation among the samples. A preliminary experiment showed that AM soaked in 50 $\mathrm{mg} / \mathrm{ml} \mathrm{ACV}$ was capable to inhibit significantly the development of HSV1 in cell cultures, as judged by the CPE extent compared to controls $(25 \% \pm 7.1$ of the monolayer vs $75 \% \pm 7.1$, $\mathrm{P}<$ 0.02). The microscopic examination of various microscopic fields allows a comprehensive evaluation of each monolayer, thus making possible to quantitate the extension of the typical morphologic alterations in each experimental point. The preliminary observation could not rule out a possible intrinsic antiviral effect of the AM, therefore antiviral-soaked AM was compared to BSS-soaked AM and control infected cells, Table 1. Whereas ACV-AM did significantly inhibit viral replication, the addition of non-treated AM had no significant effect on viral replication. By considering the viral genomes on pooled cell cultures, the figures were consistent with the results shown in Table 1: $6.2 \times 10^{5}$ HSV DNA copies for ACV-AM treated cultures compared to $20.0 \times 10^{6}$ and $25.2 \times 10^{6}$ for AM treated cultures and controls respectively.

Table 1: Antiviral activity of AM treated $60 \mathrm{~min}$ with $50 \mathrm{mg} / \mathrm{ml} \mathrm{ACV}$

\begin{tabular}{|l|ll|}
\hline Treatment & CPE extent & \\
& mean \pm SD & $n *$ \\
& & \\
\hline Control & $71.7 \pm 14.0$ & 12 \\
\hline AM & $68.3 \pm 16.4$ & 12 \\
\hline ACV-AM & $28.3 \pm 17.0^{\mathrm{a}}$ & 12 \\
\hline
\end{tabular}

CPE extent: percentage of cells showing the typical cytopathic effect

* number of experimental points

${ }^{\mathrm{a}}$ The CPE extent was significantly lower compared to controls or non-treated AM $(\mathrm{P}<0.001)$ 
Table 2 shows the antiviral activity of AM treated with different concentrations of either ACV or TFU. Antiviral activity decreased by lowering the concentration of both antivirals. The inhibition of viral growth was significant in comparison to control or non-treated AM, with the exception of AM treated with $0.08 \mathrm{mg} / \mathrm{ml}$ TFU. It has to be added that AM soaked in $10 \mathrm{mg}$ and $2 \mathrm{mg} / \mathrm{ml}$ TFU produced an aspecific toxic effect, evidenced microscopically by the rapid degeneration, within $1 \mathrm{~d}$, of the entire monolayer.

Table 2: Antiviral activity of AM treated 60min with different concentrations of ACV or $\underline{\mathrm{TFU}}$

\begin{tabular}{|l|lc|}
\hline Treatment & \multicolumn{2}{|l|}{ CPE extent } \\
& mean \pm SD & $\mathrm{n}^{*}$ \\
\hline Control & $60.0 \pm 8.9$ & 6 \\
\hline AM & $56.7 \pm 10.3$ & 6 \\
\hline ACV-AM $10 \mathrm{mg} / \mathrm{ml}$ & $31.7 \pm 7.5^{\text {a1 }}$ & 6 \\
& & \\
\hline ACV-AM $25 \mathrm{mg} / \mathrm{ml}$ & $20.0 \pm 11.0^{\mathrm{a}_{2}}$ & 6 \\
\hline ACV-AM $50 \mathrm{mg} / \mathrm{ml}$ & $13.3 \pm 5.2^{\text {a3 }}$ & 6 \\
& & \\
\hline TFU-AM $0.08 \mathrm{mg} / \mathrm{ml}$ & $40.0 \pm 0$ & 2 \\
\hline TFU-AM $0.4 \mathrm{mg} / \mathrm{ml}$ & $20.0 \pm 14.1^{\mathrm{a} 4}$ & 2 \\
& & \\
\hline
\end{tabular}

CPE extent: percentage of cells showing the typical cytopathic effect

* number of experimental points

${ }^{\mathrm{a}}$ The CPE extent was significantly lower compared to controls or non-treated $\mathrm{AM}\left({ }^{\mathrm{a}_{1}} \mathrm{P}=0.02\right.$,

${ }^{\mathrm{a} 2}$ and ${ }^{\mathrm{a}_{4}} \mathrm{P}=0.001,{ }^{\mathrm{a}_{3}} \mathrm{P}<0.001$ 


\section{Discussion}

Herpes Simplex and Varicella-Zoster viruses are potentially sight threatening. The tissue damage is sometimes directly dependent on the infectious agent replication, but is also due the inflammatory response, originally aimed to limit the infective process (harmful to the conjunctival and corneal epithelium).

AMT has been reported to be an effective surgical procedure for the reconstruction of the ocular surface and to reduce corneal inflammation.[14,22-24]

It has been recently suggested the use of AMT both in the early treatment of infectious corneal ulcers as well as in the management of acute ulcerative and necrotizing stromal herpes keratitis.[14]

Anti-infective properties of AM are probably related to its anti-inflammatory effects, thus counteracting the strong inflammatory response elicited by microorganisms, and not against the agent itself; therefore, an effective and adequate antimicrobial therapy is mandatory to ensure control of infection.

Heilingenhaus demonstrated how AMT significantly modifies the course of necrotizing stromal keratitis induced by HSV-1. The effect was associated with suppression of inflammation, rapid epithelialization, and reduction of stromal necrosis.[25,26]

In addition, in a mouse model of HSV stromal keratitis, AMT was effective in promoting corneal wound healing and in reducing inflammation, probably related to the reduced expression and activity of matrix and metallo proteinases and increased expression of tissue inhibitors of metalloproteinases.[25,27]

In a murine experimental model, the improvement of herpetic ulcerative keratitis after AMT is suggested to be due to a reduced expression and activity of Matrix Metallo-proteases MMP8 and MMP-9, increased or sustained expression of Tissue Inhibitors of metallo-proteases TIMP-1 and TIMP-2.[27] Concerns have been raised on the possibility that AMT in the 
management of infectious keratitis could be a risk factor for superinfections or viral reactivations, thus leading to a severe corneal damage and a disturbance of the normal healing process. However, besides this well known anti-inflammatory effect of AM, an intrinsic antiviral property should be taken in consideration.

Paradowska reported that human placenta contains endogenous tumor necrosis factors and interferons, possible mediators of the non specific antiviral immunity.[28]

Moreover, AM may express cistatin E, a novel human cystein proteinase effective in inhibition of viral replication.[29-31] Chronic infection of the cornea by Herpes simplex virus (HSV) remains an important cause of unilateral blindness. The development of nontoxic topical antiviral agents has been an important step forward in management of herpes keratitis.

AMT could be taken into consideration as adjunctive therapy for the anti-inflammatory and supposed direct antiviral properties of AM.[26]

The possibility to use AM to deliver drugs has been first suggested by Kim [14] and Heilinghaus [26] and then by Mencucci et al.[19] and Gicquel et al.[13] As expected, AM can absorb ACV or TFU; antiviral uptake occurs quite rapidly. The antiviral effect of treatedAM was evidenced by the development of the typical cytopathic effect as well as quantitation of viral genomes in tissue culture cells compared to control infected cells.

The reduction compared to control cultures was significant with both antivirals, and it was dose-dependent, as it was with antibiotic-treated AM. The incorporation of TFU into cellular DNA explains the aspecific toxic effect on tissue culture cells by AM treated with higher concentrations $(10 \mathrm{mg} / \mathrm{ml}$ and $2 \mathrm{mg} / \mathrm{ml})$ of the drug. Its lack of selectivity is well known; on the other hand, AM treated with higher concentrations might be used in vivo: $10 \mathrm{mg} / \mathrm{ml}$ correspond to the concentration in the eye drop preparation. The difference could be explained by the fact that in vivo dilution and dispersion of the instilled drug occur, and also 
that AM could achieve drug concentration. These observations confirm and extend our previous work on antibiotic-treated AM. As in the previous study, we could not find a significant effect by non-treated AM: the viral yield was only slightly reduced compared to controls. Our in vitro model might not be suitable to detect the intrinsic antiviral effect. On the other hand, the lack of intrinsic anti-infective activity in our in vitro model does not rule out such an activity in vivo, where the anti-inflammatory and the healing properties of AM might be implemented.

The aim of our study was not to prove the superiority of AM treated with antivirals to the antiviral alone, but the possibility to combine the anti-inflammatory properties of AM with the capability of delivering drugs. Moreover, the question about the patient's compliance: the intensive topical treatment to ensure adequate drug concentrations could be not so strictly necessary, thus improving the patient's comfort and also reducing the burden on the nursing staff; moreover, drug-soaked AM should prove superior when there are difficulties in frequent instillations such as with children, elderly, or handicapped people.

In conclusion our study, confirming and extending our previous observations on antibiotictreated AM, suggests the potential application of antiviral-treated AM in the management of herpetic ocular infections as adjunctive therapy for its anti-inflammatory, supposed direct antiviral properties and as a drug delivery system. 


\section{References}

1 Sorsby A, Symons HM. AMNIOTIC MEMBRANE GRAFTS IN CAUSTIC BURNS OF THE EYE: (Burns of the second degree). Br J Ophthalmol 1946; 30: 337-45

2 Dua HS, Gomes JA, King AJ, Maharajan VS. The amniotic membrane in ophthalmology. Surv Ophthalmol 2004; 49: 51-77

3 Azuara-Blanco A, Pillai CT, Dua HS. Amniotic membrane transplantation for ocular surface reconstruction. Br J Ophthalmol 1999; 83: 399-402

4 Solomon A, Meller D, Prabhasawat P, et al. Amniotic membrane grafts for nontraumatic corneal perforations, descemetoceles, and deep ulcers. Ophthalmology 2002; 109: 694-703

5 Sridhar MS, Bansal AK, Sangwan VS, Rao GN. Amniotic membrane transplantation in acute chemical and thermal injury. Am J Ophthalmol 2000; 130: 134-7

6 Tekin NF, Kaynak S, Saatci AO, Cingil G. Preserved human amniotic membrane transplantation in the treatment of primary pterygium. Ophthalmic Surg Lasers 2001; 32: 4649

7 Ainsworth G, Rotchford A, Dua HS, King AJ. A novel use of amniotic membrane in the management of tube exposure following glaucoma tube shunt surgery. Br J Ophthalmol 2006; 90: $417-9$

8 Espana EM, Prabhasawat P, Grueterich M, Solomon A, Tseng SC. Amniotic membrane transplantation for reconstruction after excision of large ocular surface neoplasias. $\mathrm{Br} J$ Ophthalmol 2002; 86: 640-5

9 Kee C, Hwang JM. Amniotic membrane graft for late-onset glaucoma filtering leaks. Am J Ophthalmol 2002; 133: 834-5

10 Ti SE, Tow SL, Chee SP. Amniotic membrane transplantation in entropion surgery. Ophthalmology 2001; 108: 1209-17

11 Solomon A, Espana EM, Tseng SC. Amniotic membrane transplantation for reconstruction of the conjunctival fornices. Ophthalmology 2003; 110: 93-100

12 Nubile M, Carpineto P, Lanzini M, Ciancaglini M, Zuppardi E, Mastropasqua L. Multilayer amniotic membrane transplantation for bacterial keratitis with corneal perforation after hyperopic photorefractive keratectomy: case report and literature review. J Cataract Refract Surg 2007; 33: 1636-40

13 Gicquel JJ, Bejjani RA, Ellies P, Mercie M, Dighiero P. Amniotic membrane transplantation in severe bacterial keratitis. Cornea 2007; 26: 27-33 
14 Kim JS, Kim JC, Hahn TW, Park WC. Amniotic membrane transplantation in infectious corneal ulcer. Cornea 2001; 20: 720-6

15 Singh R, Kumar D, Kumar P, Chacharkar MP. Development and evaluation of silverimpregnated amniotic membrane as an antimicrobial burn dressing. J Burn Care Res 2008; 29: $64-72$

16 King AE, Paltoo A, Kelly RW, Sallenave JM, Bocking AD, Challis JR. Expression of natural antimicrobials by human placenta and fetal membranes. Placenta 2007; 28: 161-9

17 Mermet I, Pottier N, Sainthillier JM, et al. Use of amniotic membrane transplantation in the treatment of venous leg ulcers. Wound Repair Regen 2007; 15: 459-64

18 Hasegawa T, Mizoguchi M, Haruna K, et al. Amnia for intractable skin ulcers with recessive dystrophic epidermolysis bullosa: report of three cases. J Dermatol 2007; 34: 32832

19 Mencucci R, Menchini U, Dei R. Antimicrobial activity of antibiotic-treated amniotic membrane: An in vitro study. Cornea 2006; 25: 428-31

20 Knickelbein JE, Hendricks RL, Charukamnoetkanok P. Management of herpes simplex virus stromal keratitis: an evidence-based review. Surv Ophthalmol 2009; 54: 226-34

21 In: O'Grady F LH, Finch RG, Greenwood D., ed. Antibiotic and chemotherapy. London: Churchill and Livingstone, 1977

22 Tseng SC, Prabhasawat P, Barton K, Gray T, Meller D. Amniotic membrane transplantation with or without limbal allografts for corneal surface reconstruction in patients with limbal stem cell deficiency. Arch Ophthalmol 1998; 116: 431-41

23 Lee SH, Tseng SC. Amniotic membrane transplantation for persistent epithelial defects with ulceration. Am J Ophthalmol 1997; 123: 303-12

24 Kruse FE, Rohrschneider K, Volcker HE. Multilayer amniotic membrane transplantation for reconstruction of deep corneal ulcers. Ophthalmology 1999; 106: 1504-10; discussion 11

25 Heiligenhaus A, Bauer D, Meller D, Steuhl KP, Tseng SC. Improvement of HSV-1 necrotizing keratitis with amniotic membrane transplantation. Invest Ophthalmol Vis Sci 2001; 42: 1969-74

26 Heiligenhaus A, Li H, Hernandez Galindo EE, Koch JM, Steuhl KP, Meller D. Management of acute ulcerative and necrotising herpes simplex and zoster keratitis with amniotic membrane transplantation. Br J Ophthalmol 2003; 87: 1215-9

27 Heiligenhaus A, Li HF, Yang Y, Wasmuth S, Steuhl KP, Bauer D. Transplantation of amniotic membrane in murine herpes stromal keratitis modulates matrix metalloproteinases in the cornea. Invest Ophthalmol Vis Sci 2005; 46: 4079-85 
28 Paradowska E, Blach-Olszewska Z, Sender J, Jarosz W. Antiviral nonspecific immunity of human placenta at term: possible role of endogenous tumor necrosis factors and interferons. $J$ Interferon Cytokine Res 1996; 16: 941-8

29 Bjorck L, Grubb A, Kjellen L. Cystatin C, a human proteinase inhibitor, blocks replication of herpes simplex virus. J Virol 1990; 64: 941-3

30 Korant BD, Brzin J, Turk V. Cystatin, a protein inhibitor of cysteine proteases alters viral protein cleavages in infected human cells. Biochem Biophys Res Commun 1985; 127: 1072-6

31 Ni J, Abrahamson M, Zhang M, et al. Cystatin E is a novel human cysteine proteinase inhibitor with structural resemblance to family 2 cystatins. J Biol Chem 1997; 272: 10853-8 